\title{
ПРОБЛЕМА РЕЛИГИОЗНОСТИ ГЕОРГА ТРАКЛЯ В ПЕРЕВОДЧЕСКОЙ РЕЦЕПЦИИ НА КИТАЙСКОМ ЯЗЫКЕ
}

\author{
Крашенинников Андрей Евгеньевич \\ к.филол.н. \\ Щептева Валерия Эдуардовна \\ студент \\ Гарипов Арсений Алексеевич \\ магистрант \\ ФГБОУ ВО «Северо-Восточный \\ государственный университет»
}

\begin{abstract}
Аннотация: В статье рассматривается оригинальное стихотворение лирика немецкого экспрессионизма Г. Тракля и его перевод на китайский язык. Анализируются авторские приёмы, используемые в оригинале и свойственные экспрессионистской поэтике, а также их рецепция в переводном тексте.
\end{abstract}

Ключевые слова: экспрессионизм, поэтика, перевод.

\section{THE PROBLEM OF RELIGIOUS GEORGE TRAKL IN THE TRANSLATION RECEPTION IN THE CHINESE LANGUAGE}

\section{Krasheninnikov Andrey Yevgenyevich Schepteva Valeria Eduardovna Garipov Arseny Alekseevich}

\begin{abstract}
German expressionism G. Trakl and its translation into Chinese. The author's techniques used in the original and characteristic of expressionist poetics, as well as their reception in the translated text are analyzed.
\end{abstract}

Key words: expressionism, poetics, translation.

Вокруг религиозности Георга Тракля, одного из важнейших экспрессионистских поэтов, до сих пор ведутся споры. Часть исследователей его жизни и творчества объединяет стремление представить Тракля как «һото religiosus» или, конкретнее, как «христианского человека». Однако Мартин 
Хайдеггер в работе «Georg Trakl. Eine Erörterung seines Gedichtes» высказал сомнение по поводу именно христианской религиозности Тракля выразил, рассматривая поэта через призму языческой архаики. Заслуживает внимание и мнение С. Аверинцева, представившего творчество Тракля в парадигме особой культурно-психологической формации les poètes maudits (про́клятые поэты), для которой характерно влечение к запредельному, инфернальному, а также сочувствие к народной традиции набожности. В этой дискуссии для переводчика должно стать важным то, что религиозные, богоискательские черты метафизики Тракля не подвергаются сомнению ни одной из дискутирующих сторон.

Для примера рецепции данной проблематики в переводах на китайский язык возьмём стихотворение "De profundis" [1, c. 86] Георга Тракля. Оно было опубликовано ещё при жизни автора, короткой и трагичной, и вошло в его первый и единственный прижизненный сборник, вышедший в 1913 году.

Название отсылает нас к одноимённому 130-му псалму (в католической нумерации) из Псалтири. Этот псалом - покаянная молитва. Читающий его взывает к Господу «из глубины» своего греха, своего падения и просит о снисхождении и освобождении от грехов. В католической традиции он используется для отходной молитвы, читается над умирающим. В европейской культуре этому псалом часто становился импульсом для многих композиторов создания различных музыкальных произведений: кантат, симфоний; латинский инципит псалма использовал Оскар Уайльд, когда называл свою тюремную тетрадь и т.д.

Рассмотрим текст стихотворения "De profundis":

Es ist ein Stoppelfeld, in das ein schwarzer Regen fällt.

Es ist ein brauner Baum, der einsam dasteht.

Es ist ein Zischelwind, der leere Hütten umkreist Wie traurig dieser Abend.

Am Weiler vorbei

Sammelt die sanfte Waise noch spärliche Ähren ein.

Ihre Augen weiden rund und goldig in der

Dämmerung

Und ihr Schoß harrt des himmlischen Bräutigams.

Bei ihrer Heimkehr

Fanden die Hirten den süßen Leib

Verwest im Dornenbusch.
Ein Schatten bin ich ferne finsteren Dörfern.

Gottes Schweigen

Trank ich aus dem Brunnen des Hains.

Auf meine Stirne tritt kaltes Metall. Spinnen suchen mein Herz.

Es ist ein Licht, das meinen Mund erlöscht.

Nachts fand ich mich auf einer Heide, Starrend von Unrat und Staub der Sterne.

Im Haselgebüsch

Klangen wieder kristallne Engel. 
Скорее всего, действия в стихотворении происходят в начале осени. Об этом нам говорит «Stoppelfeld» («жнивье»), т.е. поле, где уже сжата рожь, и тот факт, что сирота подбирает оставшиеся колосья («sparliche Ähren ein»). Время суток - закат, сумерки («der Dämmerung»). Стихотворение «пропитано» религиозной тематикой. «Himmlischen Bräutigams» («небесный жених») и «süßen Leib» («сладкое/сладчайшее тело») можно интерпретировать как Иисуса Христа. «Dornenbusch» («терновник»), что может отсылать нас к терновому венцу. Также здесь присутствуют такие выражения, как «Gottes Schweigen» («молчание Бога») и «kristallne Engel» («хрустальные ангелы»).

В Стихотворении прослеживается мотив смерти. «Brauner Baum» «коричневое дерево», значит, дерево без листвы, оно увяло, умерло. Свет, который погас («Es ist ein Licht, das in meinem Mund erloscht»), а также сумерки могут служить символами конца жизни, отсутствия надежды и веры в будущее. А самое очевидное - это гниющее тело в терновнике («den süßеn Leib // Verwest im Dornenbusch»). Одиноко стоящее дерево («Es ist ein brauner Baum, der einsam dasteht»), пустые хижины («leere Hütten»), сирота («Waise»), говорят нам о присутствии в стихе мотива одиночества.

Также здесь прослеживаются постапокалиптические ноты: «schwarzer Regen» («черный дождь»), который может говорить о грозе (ассоциация с тучами), Zischelwind («шепчущий ветер»), «auf einer Heide» («пустошь»), «Unrat und Staub der Sterne» («мусор и пыль от звезд»).

Рассмотрев основные мотивы и темы, затрагиваемые в стихотворении, перейдем к более подробному разбору некоторых строк произведения.

Начнем с третьей строки первой строфы. Автор использует неологизм «Zischelwind» (досл. «шипящий ветер»). Звук шипения вызывает в воображении образы змеи, т.е. чего-то зловещего. Однако в христианстве символ змеи может означать как Христа, так и дьявола в его хтонической ипостаси, олицетворяющего зло, которое человек должен в себе преодолеть.

Рассмотрим вторую строфу. Здесь особое внимание уделено глазам сиротки. Они широко открыты и золотисты («rund und goldig»), что делает их похожими на Солнце. При этом, описывая девушку, Тракль употребил слово «sanfte» («кроткая»). Сочетание этой характеристики с сияющим взглядом добавляет что-то неземное, божественное в образ сиротки. Следует отметить, что при описании глаз девушки поэтом было использовано слово «weiden» со значением «пасти(сь)», который употребляют, когда речь идет о животных, пасущихся на лугу. Первой на ум приходит овца, образ которой в 
Христианстве обозначает невинность, кротость, робость. Также в четвертой строке использовано слово «Schoß», которое переводится как колени, однако в данном контексте означает «лоно».

Обратимся к четвертой строфе. «Испиванье» Божьего молчания из родника («Brunnen des Hains» - досл. «колодцы рощ») можно интерпретировать как обращение (вероятно, покаяние) к Богу, однако без ответа.

Перейдем к пятой строфе. Во второй строке упоминается образ паука. В христианстве его идентифицировали с Сатаной и злом, т.к. он заманивает и убивает жертву (грешника, сбившегося с пути, запутавшегося в его ловушке). Следовательно, паук здесь - символ внутреннего зла - сомнения, тревоги, страха. А под «холодным металлом», возможно, подразумевается крест. Третья строка составлена необычным способом. Она переводится как «это свет, который гасит мой рот», но допускается и такой вариант: «это свет, который гаснет в моём рту». И тогда в зависимости от перевода трактовать ее можно по-разному.

Приступим к толкованию всего стихотворения целиком с учетом всех символов и образов. Вариантов трактовки, конечно, много, но мы придерживаемся версии, что все действия в произведении происходят внутри, в душе лирического героя.

В христианстве существует выражение, смысл которого в том, что Бог есть в каждом из нас. Здесь под «Богом» подразумевается доброе начало, которое присутствует во всех людях. Пастухи - это то, что помогает человеку выйти на верный путь - добродетели. Сиротка, подбирающая колосья, символизирует остатки добра в душе героя, которые он в себе «убивает» (сладкое тело, гниющее в терновнике). Тень - это злое, негативное начало героя. Он решает покаяться Господу (отсюда и название), но не слышит ответа от Него. Паук, ищущий сердце - внутреннее зло, почти поглотившее душу героя. В последней строфе описывается Страшный суд, который над ним совершается. Получается, что этот псалом читается над лирическим героем, над его «умершей» душой.

А теперь перейдем к сравнению оригинала с китайским переводом “出 自深处” [2]: 
有一片落着一阵黑雨的留茬的田地。

有一株孤零零坚着的棕色树。

有一阵围着空茅屋丝丝吹着的风。

这个黄昏多么凄凉。

村落那边

还有瘦小的孤儿在拾些许的落穗。

她的眼睛圆圆的金灿灿地盯着暮色,

她的胸怀期待着漂亮的新郎。

在回家的路上

教人发现甜蜜的身体

腐烂在刺丛里。
我是一个影子远离阴沉的村落

我从林苑的水井里饮着

上帝的沉默。

在我的额头是冰冷的金属。

蜘蛛寻找着我的心。

有一盏灯在我的口中熄灭了。

夜间我发现自己在荒原上，

上面堆满了星星的垃圾和尘埃。

在榛属从林里

又一次响起了透明的天使。

Название переведено на китайский язык, а не оставлено на латинском, что меняет восприятие произведения, т. к. лишает его религиозной окраски.

1-ая строфа. Соблюдена структура начала первых трёх строк: Es ist ein 有一片〈株〉阵. В оригинале в первой строке используется слово «Stoppelfeld» со значением «жнивьё», в китайском переводе 田地 - «обрабатываемая земля», «пашня», т.е. сельскохозяйственные угодья, где зерновые не обязательно сжаты. Во второй строке присутствует «坚着》 с основным значением вертикально, отвесно, чего в оригинале нет.

2-ая строфа. Первые 2 строки этой строфы значительно соответствуют оригиналу, поэтому перейдём к третьей. В оригинале она звучит так: «Ihre Augen weiden rund und goldig in der Dämmerung» («Ее глаза широко открыты и золотисты в сумерках»). Здесь употреблён глагол «weiden» с основным значением «пасти(сь)». В китайском варианте строка переводится как «ее глаза широко с золотисто-ярким и ослепительным взором пристально смотрят в сумерки». Глагола хотя бы близкого по значению к слову «пасти(сь)» здесь нет. В 4-й строке в оригинале используется слово «Schoß» (в данном контексте - лоно). В китайском переводчик употребил слово «胸怀》 - душа, сердце, поэт. грудь. Также, здесь употреблено выражение «漂亮的新郎» («красивый жених»), а в оригинале «himmlischen Bräutigams» («небесный жених»). Это несоответствие действительно значимо, т.к. может поменять смысл написанного. «Небесного жениха», как было сказано выше, можно интерпретировать как Господа, Иисуса Христа, в то время как прилагательное «красивый» может говорить только о хороших внешних данных ожидаемого жениха. Эта неточность могла возникнуть из-за различия культуры и религии в Китае и Европе. 
3-я строфа. Нас интересует 2-я строка. Оригинал звучит так: «Fanden die Hirten den süßen Leib». («Нашли пастухи сладкое тело».) В китайском переводе слова «пастухи» в принципе нет. Вместо него переводчик употребил 《教人» - «учить людей». Возможно, слово «教》 здесь употреблено со значением «вера, религия». Тогда данное выражение можно интерпретировать как «верующие люди», «религиозные люди». Однако «пастухов» из этого всё равно не сделать. Возможно, под «教人» подразумеваются пастыри, которые заботятся о пастве, как пастухи следят за стадом овец. Тогда строка приобретает смысл.

4-ая строфа. В оригинале лирический герой испил Божье молчание из «Brunnen des Hains» (лесной родник, досл. колодец рощи). В китайском переводе - из «林苑的水井》, что довольно сложно перевести. Либо из «колодца в имперских охотничьих угодьях», либо из «колодца в лесном саду». Так или иначе, здесь нет атмосферы заброшенности или нетронутости места, как в оригинале.

5-ая строфа. В первой строке говорится: «Auf meine Stirne tritt kaltes Metall». (На мой лоб наступает холодный металл). Здесь металл взаимодействует со лбом (наступает, касается), а в китайском варианте он непосредственно находиться (существует) в лбу.

6-я строфа. В оригинале лирический герой «оказался» в пустоши (хотя дословно это переводится как «находить себя»), в китайском переводе он «обнаруживает себя» (《发现自己») там. Причем глагол употреблен такой же, как и в 3-ей строфе (教人发现甜蜜的身体).

Как мы можем видеть, отклонений от оригинала в китайском переводе, довольно много. При этом у читателя может создаться представление об этом тексте как о религиозном стихотворении, и об авторе как глубоко воцерковлённом христианине. Однако это несколько упрощённое понимание метафизики Георга Тракля.

\section{Список литературы}

1. Тракль Г. Стихотворения. Проза. Письма. - СПб.: Symposium, 1996. -640 c.

2. De profundis (Chinese translation). - URL: https ://lyricstranslate.com/en/ de-profundis-出自深处.html (дата обращения: 24.01.2022).

(C) А.Е. Крашенинников, В.Э. Щептева, А.А. Гарипов 